\title{
The intensity of rail failure flow
}

\author{
Oleksandr Patlasov, and Yelyzaveta Fedorenko*
}

Dnipro National University of Railway Transport named after academician V. Lazaryan, Department of Railway track and Track facilities, Ukraine

\begin{abstract}
The article reveals the quantitative changes in the intensity of failure accumulations in areas with gradual introduction of high axial loads. To obtain the actual values, the authors received threedimensional array of intensity of rail failure flow. According to the results of the research, it was discovered that the main cause of failure of the rails are the defects in the main contact-fatigue origin. The main factor that impacts the intensity of the rail failure flow is the number of transmitted tonnage. The size of the axial load and curvature of the line pours weight on this process. The proposed rail failure model is a model that can be used to optimize the track maintenance system. The authors conducted a study on the identification of quantitative changes in the intensity of accumulation of track failures in areas with high axial loads and evaluated their influence on the planning of repair and road works. On the basis of the obtained results it is possible to estimate the effect of the axial load on the intensity of changes in the state of the flow rail failure flows.
\end{abstract}

\section{Introduction}

For rational management of the track facilities and the choice of the most appropriate upper structures of the track, it is necessary to determine the expected service life of the upper structure of the track as a whole and its individual elements. An analysis of the actual state of the rail facilities and repair planning on the actual state of the track is an urgent problem.

The most dangerous failures when operating the track are broken rails. To prevent this, there is a control system to detect cracks in the metal at an early stage of development and to ensure the removal of potentially hazardous rails prior to their destruction.

In order to predict the service life of the rails, it is necessary to evaluate the factors affecting them, to describe the work of rails with the help of a mathematical model, in which it is necessary to take into account the influence of the main factors of the operation of the railway track and determine the quantitative changes in the intensity of the accumulation of rail failures in areas with the gradual introduction of high axial loads.

Existing norms for determining the periodicity of carrying out track repair work depend on the screened tonnage, as well as additional criteria, including a single output of rails, which takes into account the actual state of the track. In turn, the conditions of the tracks depend on gages, radiuses and lengths of curves, their total length, ascents and descents of different lengths.

The intensity of the rail failure flow rates is established on the basis of massive observations of their work in different operating conditions.
Theoretical and experimental researches on intensity of development of defects of rails, influence on them axial loading, low temperatures, plan of the line, volumes of transportations are devoted to work of domestic and foreign scientists: IS. Baulin, S.A. Kolotushkin, E.A. Shur, NI Karpushchenko, VS Lysyuk, VO Pevzner, A. Yu. Abdurashitov, VV Ribkin, VV Kosarchuk, J. V. Ringsberg, V.A. Reichart, M. Taraf, E.H. Zachaf, O. Ususoadi, A. Zegul. [1-16].

In [17] experimental dependences of the intensity of the flow of failures were obtained.

Given that increasing the capacity of cars up to 25 tonnes / axle is considered as one of the priority areas for the development of railways, it is advisable to consider the effect of such cars on the condition of the track, namely on the condition of the rail economy in the conditions of heavy freight trains.

Taking into account that increasing the carrying capacity of carriages up to $25 \mathrm{t} /$ axle is considered as one of the priority directions of development of railways, it is expedient to consider the influence of such carriages on the state of the track.

The main objective of this study is to identify quantitative changes in the intensity of accumulation of failure flows in areas with high axial loads.

\section{Methodology and results}

It is estimated that the productivity of carriages with a load of $25 \mathrm{tf} /$ axle is higher by $7-10 \%$ due to an increase in inter-repair mileage and a reduction in the cost of traction in calculating the carriage of one ton of cargo. But a heavier carriage more intensively wears a track and leads to malfunctions [18]. 
With the development of tonnage in the process of operation, rails accumulate various damage, deformation, fatigue defects, resulting in a decrease in their reliability, more often failures occur and there is a need to reduce speed or stop the movement of trains.

The main reason for the track failure are mainly defects of contact-fatigue origin. The occurrence of contact-tired defects is a long process. Significantly influences its formation of the load on the axle from the rolling stock.

Defects originate at the stage of smelting, bottling and metal processing, and then appear at the rolling and heat treatment. The inefficiency of control at all stages of production and release of rails leads to the supply of a track complex of rails with defects of production origin.

The main criterion for total rail replacement for new and old ones is the continuous wear of the rails above the standard value or the same number of rails, as with the appointment of the appropriate type of modernization or major repair of the track. In this case, the type of accompanying work, the number of elements of fastenings and sleepers, which must be replaced, is determined by the distance of the track according to the results of commission inspections.

The complete replacement of rails, the replacement in curved sections, as well as the replacement of rails from external threads of the curved parts of the track to the straight ones, are intended provided that the rails are drained to the limits set by the Ukrzaliznytsya [19].

The main types of damages, deformations and defects of the rails are cracks, exfoliation, deflection, erosion, influx, corrosion of the metal, mechanical damage to the rails in the form of bends, screw heads or soles, internal fatigue defects in rail metal, etc.

The intensity of the single output of rails depends on the tonnage (runtime), load intensity, dynamic loads loaded on the rolling stock of the structure of the track and its condition, plan and profile of the track and other factors.

The function of the failure rate depends on the average axial load on the axle, the screened tonnage, the radius of the curve:

$$
\lambda=\mathrm{f}\left(\mathrm{P}_{a v}, \mathrm{~T}, \mathrm{R}\right)
$$

where $P_{a v}$, - average axle load in tf/axle;

$\mathrm{T}$ - screened tonnage in million tons gross;

$\mathrm{R}$ - curves radius in meters.

However, the intensity of the rail failure flows depends not only on the magnitude of the axial load, but also on the following other factors:

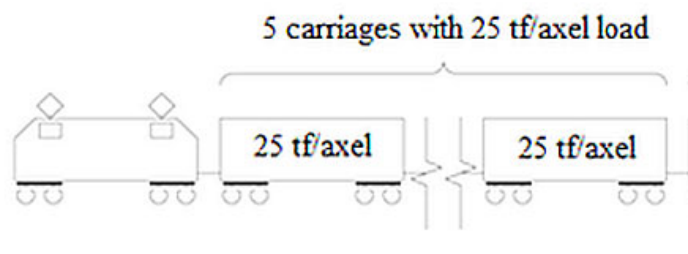

51 carriages with $23,5 \mathrm{tf} /$ axel load

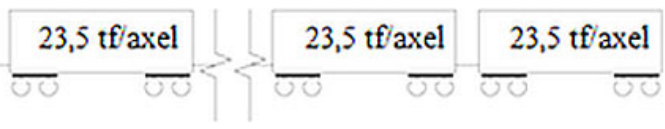

- type and structure of the upper structure of the track,

- rail steel quality,

- line plan and profile,

- load capacities,

- screened tonnage,

- types and number of repairs,

- speed of movement,

- climatic conditions, etc.

By analyzing the function of the dependence of the intensity of the rail failure flow, we can predict that with increasing axial load, the intensity of the rail failure flow increases, as well as inter-repair terms reduce. This is due to the fact that with the increase of the axial load the life of the track decreases, which is the most expensive element of the upper structure of the rail, shortening the life of the transfer services and increasing labor costs.

To solve these issues, a study was conducted on double tracks of the Pridneprovska railway distillation on Pryshyb station - Burchatsk station running line (1174 $\mathrm{km}, \mathrm{PC} 3$ ). The photo of the experimental site is shown in Fig. 1

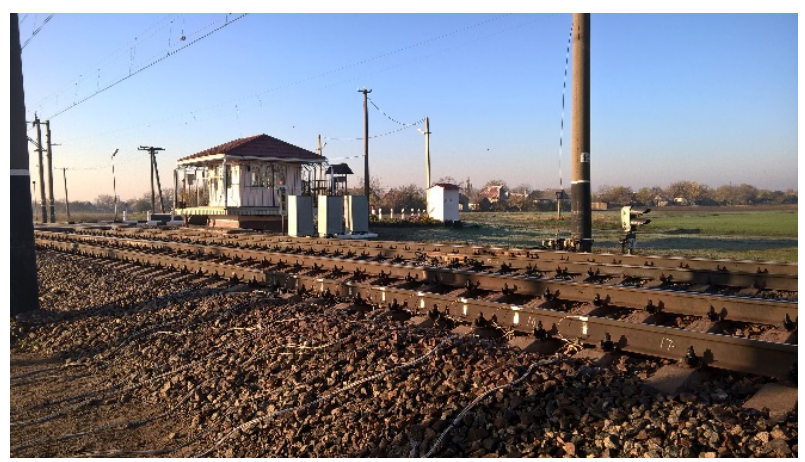

Fig. 1. Photo of the experimental site

As input data, a train No. 1762 was considered, which was moving according to the schedule, and consisted of the VL-11 locomotive, five carriages with an axial load of $25 \mathrm{tf} /$ axle and 51 carriages with an axle load of up to $23.5 \mathrm{tf} /$ axle.

The scheme of the experimental train is shown in Fig. 1. The train was moving at a speed of about 75 kmph.

Carriage dead weight and cargo weight are shown in Table 1. The experimental train was moving from the side of the Pryshyb station in the direction of Burchatsk station.

Fig. 2. Experimental train schem 
Table 1. Load capacity of train carriages

\begin{tabular}{|c|c|c|c|c|c|}
\hline No. & $\begin{array}{c}\text { Carriage } \\
\text { No. }\end{array}$ & $\begin{array}{c}\text { Dead } \\
\text { weight, } \\
\text { tons }\end{array}$ & $\begin{array}{c}\text { Tonnage, } \\
\text { tons }\end{array}$ & $\begin{array}{c}\text { Total, } \\
\text { tons }\end{array}$ & $\begin{array}{l}\text { Average axle } \\
\text { load, tf/axle }\end{array}$ \\
\hline 0 & VL-11 & 184 & 0 & 184 & 23,000 \\
\hline 1 & 62139845 & 23,5 & 76 & 99,5 & 24,875 \\
\hline 2 & 62139878 & 23,5 & 76 & 99,5 & 24,875 \\
\hline 3 & 62139852 & 23,5 & 75 & 98,5 & 24,625 \\
\hline 4 & 63584981 & 23,5 & 76 & 99,5 & 24,875 \\
\hline 5 & 62139860 & 23,5 & 76 & 99,5 & 24,875 \\
\hline \multicolumn{2}{|c|}{$\begin{array}{l}\text { average } 25 \\
\text { tf/axle }\end{array}$} & 23,5 & 75,8 & 99,3 & 24,825 \\
\hline 6 & 55081020 & 23,5 & 70 & 93,5 & 23,375 \\
\hline 7 & 62783170 & 23,5 & 70 & 93,5 & 23,375 \\
\hline 8 & 56732332 & 23,6 & 71 & 94,6 & 23,65 \\
\hline 9 & 65576373 & 23,5 & 70 & 93,5 & 23,375 \\
\hline 10 & 52183282 & 23,5 & 70 & 93,5 & 23,375 \\
\hline 11 & 55210926 & 23,5 & 70 & 93,5 & 23,375 \\
\hline 12 & 53007878 & 23,6 & 71 & 94,6 & 23,65 \\
\hline 13 & 55531487 & 23,6 & 70 & 93,6 & 23,4 \\
\hline 14 & 62073077 & 23,6 & 70 & 93,6 & 23,4 \\
\hline 15 & 55267934 & 23,6 & 70 & 93,6 & 23,4 \\
\hline 16 & 56653389 & 23,6 & 69 & 92,6 & 23,15 \\
\hline 17 & 59787184 & 23,5 & 70 & 93,5 & 23,375 \\
\hline 18 & 52283546 & 23,5 & 71 & 94,5 & 23,625 \\
\hline 19 & 52244332 & 23,5 & 70 & 93,5 & 23,375 \\
\hline 20 & 55732184 & 23,5 & 70 & 93,5 & 23,375 \\
\hline 21 & 62782917 & 23,5 & 70 & 93,5 & 23,375 \\
\hline 22 & 54008180 & 23,5 & 70 & 93,5 & 23,375 \\
\hline 23 & 62783022 & 23,5 & 70 & 93,5 & 23,375 \\
\hline 24 & 62783063 & 23,5 & 70 & 93,5 & 23,375 \\
\hline 25 & 56264443 & 23,5 & 71 & 94,5 & 23,625 \\
\hline 26 & 53148474 & 23,5 & 70 & 93,5 & 23,375 \\
\hline 27 & 60736675 & 23,5 & 70 & 93,5 & 23,375 \\
\hline 28 & 56936529 & 23,5 & 70 & 93,5 & 23,375 \\
\hline 29 & 62073556 & 23,5 & 70 & 93,5 & 23,375 \\
\hline 30 & 55483846 & 23,5 & 71 & 94,5 & 23,625 \\
\hline 31 & 60808706 & 23,5 & 70 & 93,5 & 23,375 \\
\hline 32 & 62649314 & 23,5 & 70 & 93,5 & 23,375 \\
\hline 33 & 55440044 & 23,5 & 71 & 94,5 & 23,625 \\
\hline 34 & 55531537 & 23,5 & 70 & 93,5 & 23,375 \\
\hline 35 & 62783436 & 23,5 & 70 & 93,5 & 23,375 \\
\hline 36 & 56462955 & 23,5 & 69 & 92,5 & 23,125 \\
\hline 37 & 55371645 & 23,5 & 69 & 92,5 & 23,125 \\
\hline 38 & 56843808 & 23,5 & 70 & 93,5 & 23,375 \\
\hline 39 & 62479860 & 23,5 & 70 & 93,5 & 23,375 \\
\hline 40 & 56592603 & 23,5 & 71 & 94,5 & 23,625 \\
\hline 41 & 55459895 & 23,5 & 71 & 94,5 & 23,625 \\
\hline 42 & 57656985 & 23,5 & 70 & 93,5 & 23,375 \\
\hline 43 & 63679112 & 23,5 & 70 & 93,5 & 23,375 \\
\hline 44 & 56367360 & 23,5 & 70 & 93,5 & 23,375 \\
\hline 45 & 56846421 & 23,5 & 70 & 93,5 & 23,375 \\
\hline 46 & 56479066 & 23,5 & 71 & 94,5 & 23,625 \\
\hline 47 & 61236154 & 23,5 & 70 & 93,5 & 23,375 \\
\hline 48 & 62309620 & 23,5 & 70 & 93,5 & 23,375 \\
\hline 49 & 58140310 & 23,5 & 70 & 93,5 & 23,375 \\
\hline 50 & 56002819 & 23,5 & 69 & 92,5 & 23,125 \\
\hline 51 & 56850043 & 23,5 & 70 & 93,5 & 23,375 \\
\hline 52 & 53587937 & 23,5 & 70 & 93,5 & 23,375 \\
\hline 53 & 53586806 & 23,5 & 70 & 93,5 & 23,375 \\
\hline 54 & 62932181 & 23,5 & 70 & 93,5 & 23,375 \\
\hline 55 & 56421084 & 23,5 & 69 & 92,5 & 23,125 \\
\hline 56 & 61102281 & 23,5 & 70 & 93,5 & 23,375 \\
\hline & $\begin{array}{l}\text { erage } 23,5 \\
\text { tf/axle }\end{array}$ & 23,51 & 70,08 & 93,59 & 23,398 \\
\hline
\end{tabular}

Today, Ukraine already has a rolling stock with an axle load of $25 \mathrm{tf} / \mathrm{axle}$ and its implementation is considered, but the actual axle load is $23.5 \mathrm{tf} / \mathrm{axel}$. To calculate, let us compare the value of the intensity of the rail failure flow, depending on the average of the actual and increased axial load.

The actual average axle load for the carriage of cargo shall be the following (2):

$$
P_{\text {av cargo }}=\frac{\mathrm{T}_{c a r}}{n_{\text {axis }}}
$$

where $\mathrm{T}_{c a r}$ - dead weight of a loaded carriage in tons;

$n_{\text {axis }}$ - number of axels in the carriage;

Actual average axle load for empty carriages (3):

$$
P_{\text {empty cargo }}=\frac{\mathrm{T}_{c a r}}{n_{\text {axis }}}
$$

where $\mathrm{T}_{c a r}-$ dead weight of an empty carriage in tons;

$n_{\text {axis }}-$ number of axels in the carriage;

The following initial documentation of the distances and the service of the track was used for obtaining the initial data: longitudinal profiles, rail-sleeper-ballastinc map, record of rails taken from the main tracks (form PU-4), annual reports of the track distance.

For the selected experimental sites and each element of the plan, the following parameters were determined:

- load capacity;

- average axle load;

- description of plan and profile;

- the term of the last major repair;

- screened tonnage after the last upgrade.

From each removed rail from a track, the following aspects were fixed:

- direction;

- track number;

- kilometer and number of the rail;

- day, month, and year of rail removal;

- defective classification number [20].

One of the main indicators that characterize the system reliability of the track is the parameter of the rail failure flow. The rate of failure of the rails is the number of defective rails, which are replaced by $1 \mathrm{~km}$ referenced to the unit of the passed tonnage:

$$
\lambda_{i j k}=\frac{N_{i j k}}{L_{i j k} \cdot \Delta T_{i j k}}
$$

where $N_{i j k}$ - the number of rails replaced on the experimental plot, pes;

$L_{i j k}$ - length of the experimental plot, km;

$\Delta T_{i j k}$ - screened tonnage, million tons gross;

$i, j, k$ - the levels of the axial load test factors, the line plan and the screened tonnage.

To obtain the actual values it is necessary to get three-dimensional array of intensity of rail failure flow. The size of the array is determined by the number of levels of each of the test factors (axial load, plan of the line, screened tonnage) [21]. 
The algorithm of calculation begins with the sorting of data on each replaced rail in relations with levels of influencing factors. As a result of sorting, the values of the indexes $i, j, k$ are found. Thus, the number of replaced rails is determined at all levels of the analyzed factors.

The next step is to determine the length of the track segment, which corresponds to the characteristics of each element of the three-dimensional array $L_{i j k}$. Each elementary segment is understood as a segment of the track, where any chosen for the analysis change. Moreover, it was taken into account that one and the same real elementary segment can be entered into a cell of the array, which are different values of the screened tonnage. For example, if the factor "screened tonnage" is divided at the level of 50 million tons gross, then the length of one and the same elementary segment can be entered in the first, second, etc. levels, as the same that through this real segment of the track the tonnage of 0 to 50 million tons gross can be screened, from 50 to 100 , etc. It is also taken into account that during a certain period of operation of the section of the track there are no data on the failure of rails in this area. In this case, the length of this section in the corresponding cell of the screened tonnage is not entered. If the level of the screened tonnage is lower than the level of the factor at the site, then the "length" changes in proportion to the actual tonnage missed.

After filling all the cells of the three-measuring array with the number of replaced rails and the "length" of the sections according to the formula (4), the intensity of the rail failure flow is determined.

Taking into account that the levels of all factors being analyzed are intervals, for each value of the intensity of the rail failure flow, the value of the screened tonnage, the axial load and the radius of the curve were determined.

For the implementation of the dispersion analysis, factor 3 was adopted: the line plan (straight and curves with a radius of $600 \mathrm{~m}$ ) and the screened tonnage of 800 million tons gross, and variants of axial load, namely: $5 \%$ of carriages loaded $25 \mathrm{tf} /$ axel, $95 \%$ - up to $23.5 \mathrm{tf} / \mathrm{axel}$ $10 \%$ of carriages loaded $25 \mathrm{tf} / \mathrm{axel}, 95 \%$ - up to $23.5 \mathrm{tf} /$ axel $25 \%$ of carriages loaded $25 \mathrm{tf} /$ axel, $95 \%$ - up to $23.5 \mathrm{tf} / \mathrm{axel}$ $50 \%$ of carriages loaded $25 \mathrm{tf} /$ axel, $95 \%$ - up to $23.5 \mathrm{tf} / \mathrm{axel}$ $75 \%$ of carriages loaded $25 \mathrm{tf} / \mathrm{axel}, 95 \%$ - up to $23.5 \mathrm{tf} / \mathrm{axel}$ $100 \%$ of carriages loaded $25 \mathrm{tf} / \mathrm{axel}, 95 \%$ - up to $23.5 \mathrm{tf} / \mathrm{axel}$

The results of calculating the intensity of the rail failure flow are shown in Table 2 .

Table 2. Results of calculating the intensity of the rail failure flow

\begin{tabular}{|l|c|c|c|}
\hline $\begin{array}{c}\text { Average } \\
\text { axial load, } \\
\text { tf / axel }\end{array}$ & $\begin{array}{c}\text { The } \\
\text { curvature of } \\
\text { the site. }\end{array}$ & $\begin{array}{c}\text { Missed } \\
\text { tonnage, } \\
\text { million tons }\end{array}$ & $\begin{array}{c}\text { The parameter of } \\
\text { the flow of the rail, } \\
\text { pcs }\end{array}$ \\
\hline 23,46935 & 0.0143478 & 800 & 0,118149899 \\
\hline 23,5407 & 0.0143478 & 800 & 0,118160136 \\
\hline 23,75475 & 0.0143478 & 800 & 0,118190848 \\
\hline 24,1115 & 0.0143478 & 800 & 0,118242033 \\
\hline 24,46825 & 0.0143478 & 800 & 0,118293219 \\
\hline
\end{tabular}

\section{Conclusion}

According to the results of researches, it has been discovered that the main cause of track failure are mainly defects of contact-fatigue origin. The main factor that impacts the intensity of the rail failure flow is the number of transmitted tonnage. The size of the axial load and curvature of the line pours weight on this process. The track failure model is proposed. Which can be used to optimize the track maintenance system.

\section{Literature}

1. Baulin I. S., Dyakov V. N., Uskova O. N. et al. Investigation of the mechanism of contact-fatigue damage (defect 82 and 64) / Vesnik VNIIZhT. No. 4, 1962 .- p.34-39

2. Kolotyshkin S. A., Dyakov V. N., Poroshin V. L., Baulin I. S. Detection of internal longitudinalinclined cracks in the track heads / Vesnik VNIIZhT. Edition 1, 1973, p. 41-43

3. Tsukanov P. P. Operational stability of tracks of modern production / Research on heavy type tracks. Collection of VNIIZhT scientific papers. M :. 1961. P. 4-31

4. Shur E. A., Konyukhov A. D. Influence of residual stresses in hardened tracks on the emergence and propagation of fatigue cracks in cyclic bending / Residual stresses and strength of railway tracks. VNIIZhT. Edition.491

5. Shur E. A. On the choice of permissible stresses under the strength of track calculations / Vesnik VNIIZhT. Edition 8, 1977, pp. 38-41

6. Shur E. A., Kiselev T. N., Poroshin V. L., Beyserov M. S. Durability of tracks with cracks / Vesnik VNIIZhT. Edition 5, 1984, p. 48-52

7. Karpushchenko N. I. Planning of repairs of the railroad according to its the state // G. K. Shchepotin Improving the reliability and efficiency of the railroad. / Under edition if N. I. Karpushchenko. Collection of scientific papers - Novosibirsk, 1991, p. 122.

8. Lysyuk V. S. Fundamentals of the methodology for calculating failures and inter-repair resources of the railway track for damages of tracks // VNIIZhT. M., 1983. - 57 p. CNIITEI MPS Dep 25.02.83, № 2120 ZHD-D83 // Railway Transport Magazine abstract, No. 6, 1983.

9. Pevzner V.O. To improve planning of track works. // Track and track facilities, 1993, № 9, - P. 10-12.

10. Abdurashitov A. Yu. The regularities of the formation of contact-fatigue defects. // Track and track facilities, 2002, No. 11, pp. 16-20.

11. Rybkin V. V. Mathematical model of track failure due to fatigue defects // A. M. Patlasov. Aspects of the interaction of the track and the rolling stock. Works of DIIT. - D., 1990. - P. 52-58.

12. Ringsberg J.W. Cyclic ratcheting and failure of $a$ pearlitic rail steel // Fatigue \& Fract. Engng. Mater.\& Struct. - 2000. - 23. - P. $747-758$ 
13. Reichart V.A. Analysis of rail defects // Path and track economy. - 2001. - №4. - P. 22 - 25

14. Kosarchuk V.V., Agarkov O.V. Prediction of durability of rails by the criterion of occurrence of contact fatigue cracks // Proc. Sciences. to wash DUIT. Transport Systems and Technologies Series. 2012. - Vip. 20. - P. 77 - 90.

15. Taraf M., Zahaf E.H., Oussouaddi O., Zeghloul A. Numerical analysis for predicting the rolling contact fatigue crack initiation in a railway wheel steel // Tribology International. - 2010. - 43. - P. 585 - 593.

16. Kosarchuk V.V., Danilenko E.I., Agarkov O.V., Rafalsky O.Y. Influence of the profile of car wheels on the level of contact stresses in rails // Coll. Sciences. to wash DUIT. Transport Systems and Technologies Series. - 2018. - Vip. 31. - P. 3

17. Rybkin V. V., Umanov M. I., Bal O. M. Individual track output as an important factor for forecasting the period of repair of a track // Bulletin of the Dnipropetrovsk National University of Railway Transport named after academician V. Lazaryan. 2007. - Ed. 18. - P. 62-70. - Access mode: http://nbuv.gov.ua/UJRN/vdnuzt 2007_18_16
18. Rybkin, V. V. Stress-deformed state of the track in the interaction of wagons with increased axial load / V. V. Rybkin, A. M. Patlasov, V. I. Klimov // Problems of mechanics of railway transport. Increase of reliability and perfection of structures of rolling stock: theses. doc. All Union. conf. (Dnipropetrovsk, May 1988). - Dnipropetrovsk, 1988. - P. 96.

19. Regulations on conducting scheduled maintenance and repair works on railways of Ukraine: CP-0287: Order of Ukrzaliznytsia dated 11/3/2014 № 470-CZ / A. Babenko, G. Linnik, K. Moiseenko [et al]. - Kyiv, 2015. - 45 p.

20. Classification and catalog of defects and damage of elements of switching transfers and tracks of Ukrainian railways: CP 0060 - 2000.

21. Patlasov A. M. Improvement of the system of planning of repairs of a railway tracks: diss. Cand. of Tech. Sciences: 05.22.06 / Alexander Mikhailovich Patlasov; St. Petersburg Institute of Ing. Railway Transport Engineering - St. Petersburg, 1991. - p. 167. 